The University of Maine

DigitalCommons@UMaine

Earth Science Faculty Scholarship

Earth Sciences

$12-1-2006$

\title{
The Aeolian Flux of Calcium, Chloride and Nitrate to the McMurdo Dry Valleys Landscape: Evidence from Snow Pit Analysis
}

Rebecca A. Witherow

W. Berry Lyons

Nancy A.N. Bertler

Kathleen A. Welch

Paul Andrew Mayewski

University of Maine-Main, paul.mayewski@maine.edu

See next page for additional authors

Follow this and additional works at: https://digitalcommons.library.umaine.edu/ers_facpub

Part of the Earth Sciences Commons

\section{Repository Citation}

Witherow, Rebecca A.; Lyons, W. Berry; Bertler, Nancy A.N.; Welch, Kathleen A.; Mayewski, Paul Andrew; Sneed, Sharon B.; Nylen, Thomas; Handley, Michael J.; and Fountain, Andrew, "The Aeolian Flux of Calcium, Chloride and Nitrate to the McMurdo Dry Valleys Landscape: Evidence from Snow Pit Analysis" (2006). Earth Science Faculty Scholarship. 99.

https://digitalcommons.library.umaine.edu/ers_facpub/99

This Article is brought to you for free and open access by DigitalCommons@UMaine. It has been accepted for inclusion in Earth Science Faculty Scholarship by an authorized administrator of DigitalCommons@UMaine. For more information, please contact

um.library.technical.services@maine.edu. 


\section{Authors}

Rebecca A. Witherow, W. Berry Lyons, Nancy A.N. Bertler, Kathleen A. Welch, Paul Andrew Mayewski, Sharon B. Sneed, Thomas Nylen, Michael J. Handley, and Andrew Fountain 


\title{
The aeolian flux of calcium, chloride and nitrate to the McMurdo Dry Valleys landscape: evidence from snow pit analysis
}

\author{
REBECCA A. WITHEROW ${ }^{1}$, W. BERRY LYONS ${ }^{1 *}$, NANCY A.N. BERTLER ${ }^{2,3,5}$, KATHLEEN A. WELCH $^{1}$, \\ PAUL A. MAYEWSKI ${ }^{3}$, SHARON B. SNEED ${ }^{3}$, THOMAS NYLEN ${ }^{4}$, MICHAEL J. HANDLEY $^{3}$ and \\ ANDREW FOUNTAIN ${ }^{4}$ \\ ${ }^{1}$ Byrd Polar Research Center and the Department of Geological Sciences, The Ohio State University, Columbus, OH 43210-1002, USA \\ ${ }^{2}$ Antarctic Research Centre, Victoria University of Wellington, PO Box 600, Wellington, New Zealand \\ ${ }^{3}$ Climate Change Institute, University of Maine, Orono, ME 04469, USA \\ ${ }^{4}$ Departments of Geology and Geography, Portland State University, Portland, OR 97207-0751, USA \\ 5GNS Science, 1 Fairway Drive, Avalon, Lower Hutt 5010, New Zealand \\ *corresponding author: lyons.142@osu.edu
}

\begin{abstract}
We have determined the flux of calcium, chloride and nitrate to the McMurdo Dry Valleys region by analysing snow pits for their chemical composition and their snow accumulation using multiple records spanning up to 48 years. The fluxes demonstrate patterns related to elevation and proximity to the ocean. In general, there is a strong relationship between the nitrate flux and snow accumulation, indicating that precipitation rates may have a great influence over the nitrogen concentrations in the soils of the valleys. Aeolian dust transport plays an important role in the deposition of some elements (e.g. $\mathrm{Ca}^{2+}$ ) into the McMurdo Dry Valleys' soils. Because of the antiquity of some of the soil surfaces in the McMurdo Dry Valleys regions, the accumulated atmospheric flux of salts to the soils has important ecological consequences. Although precipitation may be an important mechanism of salt deposition to the McMurdo Dry Valley surfaces, it is poorly understood because of difficulties in measurement and high losses from sublimation.
\end{abstract}

Received 3 January 2005, accepted 30 May 2006

Key words: elements, fluxes, glaciers, Latitudinal Gradient Project, salts in soils

\section{Introduction}

The geochemistry of the McMurdo Dry Valleys (MCM) soils has been investigated for over 40 years. These hyperarid soils accumulate salts and the origins of these salts, their sources, and the processes involved in their accumulation have been the subject of debate (Gibson 1962, Bowser et al. 1970, Claridge \& Campbell 1977, Keys \& Williams 1981). The atmospheric input of ions such as $\mathrm{NO}_{3}^{-}, \mathrm{SO}_{4}^{2-}, \mathrm{Cl}^{-}$, and $\mathrm{Ca}^{2+}$ contribute greatly to the longterm geochemistry of the MCM soils. Yet the flux of these individual salts to the soils has not been established. The calculation of elemental fluxes from snow pit and/or ice core data is not new, as the desire to understand past atmospheric loadings has been a major preoccupation of climatologists and palaeo-atmospheric chemists alike. In this work, we are not interested in the atmospheric concentration, as such, but rather how the atmospheric input varies spatially. Although there is evidence that a percentage of the cations of these salts can come from the weathering of minerals in the soils, this appears to be a major process only where abundant liquid water is available, such as in the hyporheic zone of the stream channels or lake margins (Nezat et al. 2001, Gooseff et al. 2002, Lyons et al. 2002, Green et al. 2005). It is now clear that the largest accumulation of salts, especially the anions, come from atmospheric input (Keys \& Williams 1981, Graham et al. 2002). Recent stable isotopic measurements in the MCM soils have demonstrated an atmospheric source for sulphate and nitrate salts (Bao et al. 2000, Sheppard et al. 2002, Michalski et al. 2005). The nitrate is wet deposited from tropospherically and stratospherically produced $\mathrm{HNO}_{3}$ (Michalski et al. 2005). Sulphate may be dry deposited in sea salt, or oxidized sulphur compounds may be deposited by precipitation. The two modes of sulphur deposition are geographically separate in the MCM, with higher proportions of sea salt sulphate near the coast and higher proportions of non-sea salt sulphate at higher elevations (Bao et al. 2000). Chloride salts are also marine-derived and dry deposited as their abundance decreases inland, away from the marine source (Keys \& Williams 1981). Much of the readily soluble $\mathrm{Ca}^{2+}$ found on the landscape may be introduced as dust from aeolian transport (Lyons et al. 2003, Foley 2005), although the ultimate source of the dust is thought to be local, as opposed to long-distance (Fortner et al. 2005).

In this paper, we use snow pit profiles and snow accumulation rates from a number of glaciers in the MCM region to establish the geographical variation in the flux of these salts for the first time as a contribution to the Latitudinal Gradient Project (Howard-Williams et al. 
2006). The fluxes determined from the glaciers provide a highly accurate quantification of the net flux of these salts to the MCM, as conventional measurements of snowfall have proven to be extremely difficult in this environment. Because the atmospheric deposition of nitrate is the primary source of nitrogen input to the soils and high soil salinities inhibit invertebrate populations (Powers et al. 1998, Nkem et al. 2005), these measurements have important ecological implications. We present the regional aeolian fluxes of $\mathrm{NO}_{3}^{-}, \mathrm{Cl}^{-}$, and $\mathrm{Ca}^{2+}$ for the MCM. These ions were chosen, in part, because their sources are very different and represent input from the stratosphere, the marine troposphere, and local dust, respectively.

\section{Study sites}

The MCM are the largest ice-free region in Antarctica and consist of soils, glaciers, ephemeral streams and perennially ice-covered lakes. This location is a polar desert ecosystem and has served as a Long-Term Ecological Research (LTER) site since 1993. Mean annual temperatures range from -30.0 to $-14.8^{\circ} \mathrm{C}$ depending on the site and the period of measurement (Doran et al. 2002). In general the valleys exhibit a distinct north-south gradient, with Victoria Valley being the coldest valley and Taylor Valley the warmest. Mean annual wind speed increases with proximity to the polar plateau, with strong winter katabatic winds being a primary meteorological feature of this region (Doran et al. 2002). These winds flow essentially west to east and are thought to have a major influence on aeolian deposition in the valleys (Lancaster 2002, Fortner et al. 2005). During summer however, the dominant wind direction is onshore carrying a higher marine aerosol loading (Bertler et al. 2004b).

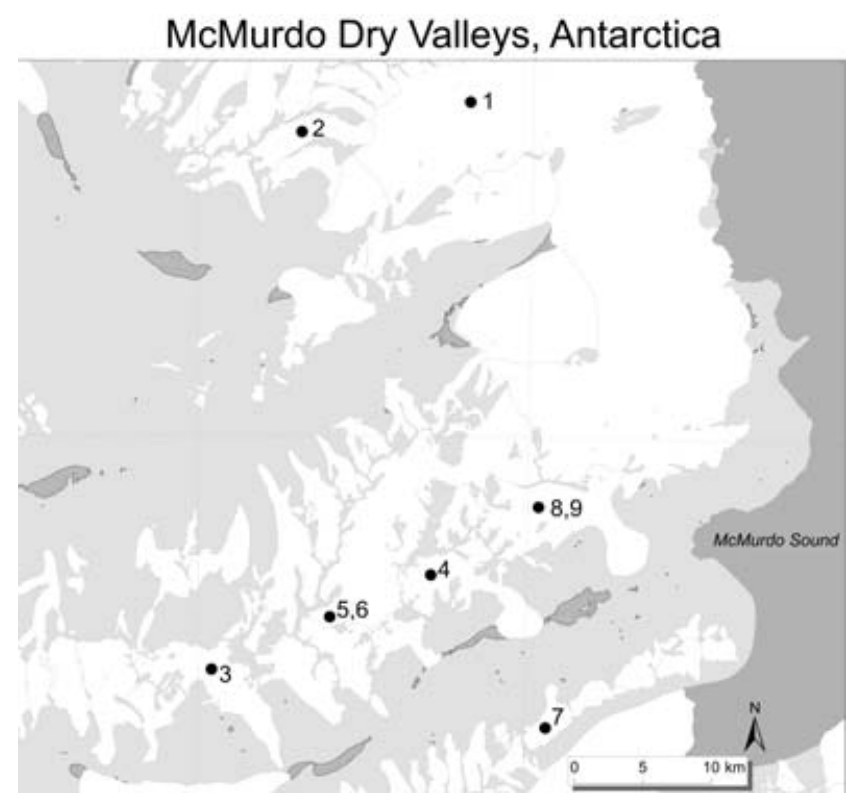

Fig. 1. Overview map of the study area. $1=$ Victoria Lower Glacier, 2 = Baldwin Valley Glacier, 3 = Rhone Glacier, 4 = Canada Glacier, $5=$ Newall Glacier (1), $6=$ Newall Glacier (2), $7=$ Howard Glacier, $8=$ Commonwealth Glacier (1), $9=$ Commonwealth Glacier (2).

On MCM glaciers, the altitude delineating the zone of mass accumulation from ablation, the equilibrium line altitude (ELA), has a positive relationship to distance inland (Fountain et al. 1999b). The sampling sites in Taylor Valley were located at least $100 \mathrm{~m}$ above the estimated ELA (Fountain et al. 1999b). Although there have been no direct observations of melting at the sampling site altitudes, sporadic ice lenses suggest that at least partial melting occurs occasionally. Annual layers of snow may be

Table I. Snow pit characteristics. Mean accumulation rates for the Canada and Rhone Glaciers are based on Fountain (2005). The mean accumulation rate for the Howard Glacier is from Fountain (2005). Data for the Newall Glacier are from Welch (1993).

\begin{tabular}{|c|c|c|c|c|c|c|}
\hline Site & $\begin{array}{l}\text { Pit depth } \\
\quad(\mathrm{m})\end{array}$ & Record length & $\begin{array}{l}\text { Mean density } \\
\left(\mathrm{g} \mathrm{mL}^{-1}\right)\end{array}$ & $\begin{array}{l}\text { Mean accumulation } \\
\left(\mathrm{cm} \text { water } \mathrm{yr}^{-1}\right)\end{array}$ & $n$ & Error \\
\hline Victoria Lower Glacier & 4.1 & $\begin{array}{c}27 \mathrm{yr} \\
1971-1998\end{array}$ & 0.349 & 3.69 & 28 & $\begin{array}{c} \pm 1 \mathrm{yr} \\
4 \%\end{array}$ \\
\hline Baldwin Valley Glacier & 4.2 & $\begin{array}{c}41 \mathrm{yr} \\
1958-99\end{array}$ & 0.405 & 3.21 & 40 & $\begin{array}{c} \pm 1 \mathrm{yr} \\
2 \%\end{array}$ \\
\hline Rhone Glacier & 2 & ND & 0.26 & 3 & 66 & \\
\hline Newall Glacier (1) & 6 & $\begin{array}{c}48 \mathrm{yr} \\
1940-1988\end{array}$ & & 5.0 & 282 & $\begin{array}{l} \pm 5 \mathrm{yr} \\
10 \%\end{array}$ \\
\hline Newall Glacier (2) & 4 & $\begin{array}{c}46 \mathrm{yr} \\
1942-1988\end{array}$ & & 3.3 & 274 & $\begin{array}{c} \pm 5 \mathrm{yr} \\
11 \%\end{array}$ \\
\hline Howard Glacier & surface & & ND & 1.30 & 1 & $\begin{array}{c}\sigma \text { mass balance } \\
11 \%\end{array}$ \\
\hline
\end{tabular}


redistributed by the high winds in Taylor Valley and sastrugi have been observed in snow pits. The effect of this mixing on the preservation of annual layers varies according to the glacier being studied, for example, annual layers were not discernable in the Canada Glacier and Rhone Glacier snow pits, yet the layers appeared to be well preserved in both snow pits on the Commonwealth Glacier (Fig. 1).

\section{Materials and methods}

Glacier ice has long been utilized to determine the variation and flux of chemicals from the atmosphere to polar regions (e.g. Legrand \& Mayewski 1997). Research on the glaciochemistry of the MCM until recently has been focused either on a few chemical species (Mayewski \& Lyons 1982) or on the surficial composition of the snow (Lyons et al. 2003). Some work has tied the variation with respect to time of the chemistry of glacier ice to that of climatic changes (Welch 1993, Bertler et al. 2004a, 2004b).

Chemical measurements from snow pits on five glaciers were obtained in this work (Fig. 1, Table I). These glaciers include Commonwealth, Canada and Rhone glaciers in Taylor Valley and Victoria Lower Glacier and Baldwin Valley Glacier in Victoria Valley (Table I). The Taylor Valley data were collected and analysed at the Byrd Polar Research Center at The Ohio State University-Portland State University (BPRC-OSU/PSU) group while the Victoria Valley data were collected and analysed by the Victoria University of Wellington/University of Maine, Orono (VUW/UMO) group. Densities for the Commonwealth Glacier were collected by the University of Maine group (Williamson 2006). In addition, we include surface measurements from the Howard Glacier, Taylor Valley (Lyons et al. 2003) and snow pit data from the Newall Glacier (Welch 1993)

\section{Taylor Valley snow}

After the initial excavation of the snow pit using standard avalanche shovels, the sampling wall face was scraped off using polypropylene shovels that had been cleaned by successive soakings in $18 \mathrm{M} \Omega$ MilliQ ${ }^{\mathrm{TM}}$ water. The snow was prepared for sampling by using a spatula to loosen the section. The sampling device was then slid into the snow layer and gently manipulated to loosen the compacted snow. The snow sample was placed into a $500 \mathrm{~mL}$ HDPE container that had been previously soaked overnight and rinsed three times with $18 \mathrm{M} \Omega \mathrm{MilliQ}^{\mathrm{TM}}$ water at Crary Laboratory and transported to the field site empty.

Samples remained frozen until immediately prior to analysis at McMurdo Station using a Dionex DX-120 ion chromatograph (IC). The technique, a modification of Welch et al. (1996), implements a sample loop of approximately $400 \mu \mathrm{L}$ for all standards and samples. A Dionex IonPac AS14 analytical column (4 x $250 \mathrm{~mm}$ ) and
AG14 guard column $(4 \times 50 \mathrm{~mm})$ were used with an ASRS Ultra Anion Self-Regenerating Suppressor to analyse major anions. The eluent was a $3.5 \mathrm{mM} \mathrm{Na} \mathrm{CO}_{3}$ and $1.0 \mathrm{mM}$ $\mathrm{NaHCO}_{3}$ solution with a pump flow-rate of $1.2 \mathrm{~mL} \cdot \mathrm{min}^{-1}$. Cations were analysed using the Dionex IonPac CS12A analytical column (4 x $250 \mathrm{~mm}$ ), a CG12A guard column $(4 \times 50 \mathrm{~mm})$, and a CSRS Ultra Cation Self-Regenerating Suppressor. The $1.3 \%$ methanesulphonic acid eluent had a flow-rate of $1.2 \mathrm{~mL} \cdot \mathrm{min}^{-1}$.

A stock standard solution was created from several singleelement standards. The multi-element stock standard was diluted to produce six calibration standards with a range of concentrations that covered the estimated concentrations of the samples. Analytical and filtration blanks were run before, during, and after samples. An independent multielement standard was analysed after creating a calibration curve to satisfy quality assurance and quality control. Several sample duplicates were analysed for recovery comparisons and were used for precision analysis. Maximum analytical variability between samples was $\pm 3.3 \%$ for $\mathrm{Cl}^{-}, \pm 10.9 \%$ for $\mathrm{Ca}^{2+}$, and $\pm 14.4 \%$ for $\mathrm{NO}_{3}{ }^{-}$.

\section{Victoria Valley snow}

Snow pit samples were collected with $1 \mathrm{~cm}$ resolution. $\mathrm{Ca}^{2+}$ concentrations (VLG snow profile) were measured using Dionex $^{\mathrm{TM}}$ ion chromatography with Dionex IonPac CS12 column and a $20 \mathrm{mM}$ methanesulphonic acid eluent. $\mathrm{Cl}^{-}$and $\mathrm{NO}_{3}^{-}$(VLG snow profiles) were measured with a Dionex AS11 column, $6.0 \mathrm{mM} \mathrm{NaOH}$ eluent for both reproducibility within $\pm 3 \%(n=213)$ and $\pm 10 \%(n=46)$ for low concentration (1-10 $\left.\mu \mathrm{g} \cdot \mathrm{L}^{-1}\right)$ samples. Samples (BVG snow profile) were analysed for $\mathrm{Ca}^{2+}$ using a PerkinElmer Optima 3000 XL axial inductively coupled plasma optical emission spectrometer with a CETAC ultrasonic nebulizer (ICP-OES-USN). Yttrium was used as an internal standard. External quality control samples were run every ten samples. Reproducibility was within $< \pm 5 \%(n=130)$. Control samples of frozen ultrapure water (18 M $\Omega$ MilliQ ${ }^{\mathrm{TM}}$ ) were measured with both systems and show that no significant contamination occurred during sampling and processing of the samples.

\section{Flux calculations}

Two snow pits on the Commonwealth Glacier were dated with $\mathrm{a} \pm 1$ year accuracy using $\mathrm{Na}^{+}$peaks, which commonly define the autumn when low sea-ice extent and high maritime winds deposit large amounts of sea salt on glacial surfaces (Legrand \& Mayewski 1997). Seasonal variations in the chemistry input and gross beta activity measurements were used to date the Newall Glacier and Victoria Lower Glacier snow profile record with \pm 5 years and \pm 1 year accuracies respectively (Welch 1993, Bertler et al. 2004b). The isotopic values from the Victoria Lower Glacier were 


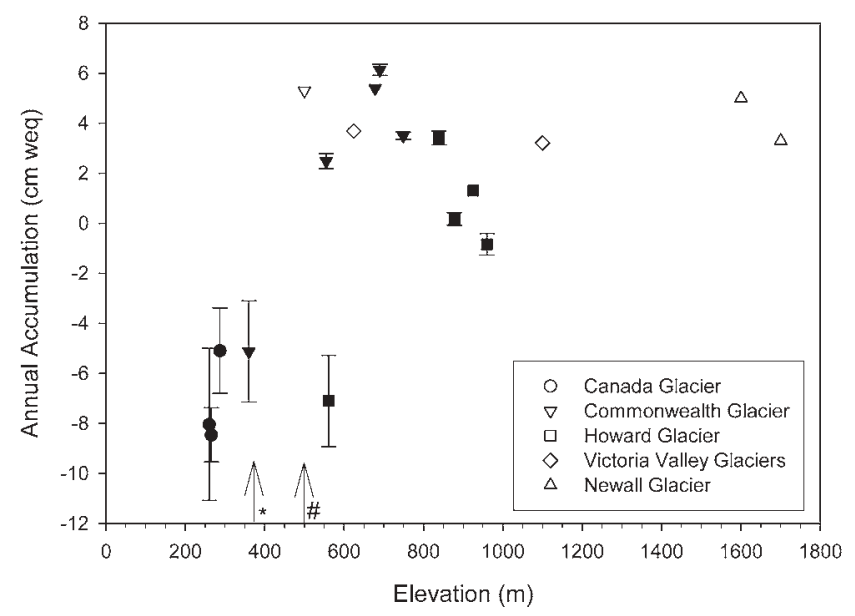

Fig. 2. Mass balance data from 1993-2004 for selected locations in the MCM. Black symbols are from the work of Fountain (2005). White symbols are from this study. Equlibrium line altitudes for the (*) Canada and Commonwealth glaciers and (\#) Howard Glacier (Fountain et al. 1999b).

converted to temperature using $2 \mathrm{~m}$ surface temperature data from Lake Vida (provided by the McMurdo Dry Valleys Long-Term Ecological Research Project) (Bertler et al. 2004b). The comparison between Scott Base, Marble Point, and MCM-LTER summer temperatures indicates a common climate history (Bertler et al. 2004a). This relationship was applied to tune the isotope record of the remaining snow profile (BVG) to Scott Base summer temperatures (Bertler et al. 2006). Annual accumulation was calculated using measured density and snow layer thickness.

Mass balance measurements have been recorded on several glaciers in the MCM since 1993 (Fountain 2005).
Mass balance averages of individual stakes in or near the accumulation zones of the Canada, Commonwealth, and Howard Glaciers were identified and compared against elevation (Fig. 2). Locations above the equilibrium line altitude (ELA) typically show little variation in precipitation with elevation. Because precipitation is independent of elevation, it is appropriate to assume that sample locations on the Canada and Rhone Glaciers receive approximately $3 \mathrm{~cm} \cdot \mathrm{yr}^{-1}$ (water equivalent), similar to other accumulation zones in the MCM.

Flux data, $f_{i}$, were calculated,

$$
f_{i}=C_{i} \cdot b
$$

and

$$
b=\left(\sum_{i=1}^{n} b_{i}\right) \cdot n^{-1}
$$

where $C_{i}$ is the average concentration of an analyte in a snow pit and $b$ is the average annual accumulation rate.

Because the Commonwealth Glacier has defined annual layers, fluxes were evaluated using two other approaches to check the precision and to avoid potential errors exclusive to Eq. (1). The first approach is defined as,

$$
f_{1}=C_{i} \cdot b_{1}
$$

and

$$
b_{1}=d \cdot t^{-1}
$$

where $C_{i}$ is the mean concentration of an analyte over the entire depth of the snow pit. $b_{1}$ is the mean annual accumulation where $d$ is the depth of the snow pit and $t$ is the time represented by that pit. The second approach utilizes the discrete layers to calculate the average of the annual fluxes for all represented years given year, $f_{a n n}$,

Table II. Snow pit location, concentration, and flux data. Data from the Newall Glacier are from Welch (1993). Concentration data from the Howard Glacier are from Lyons et al. (2003).

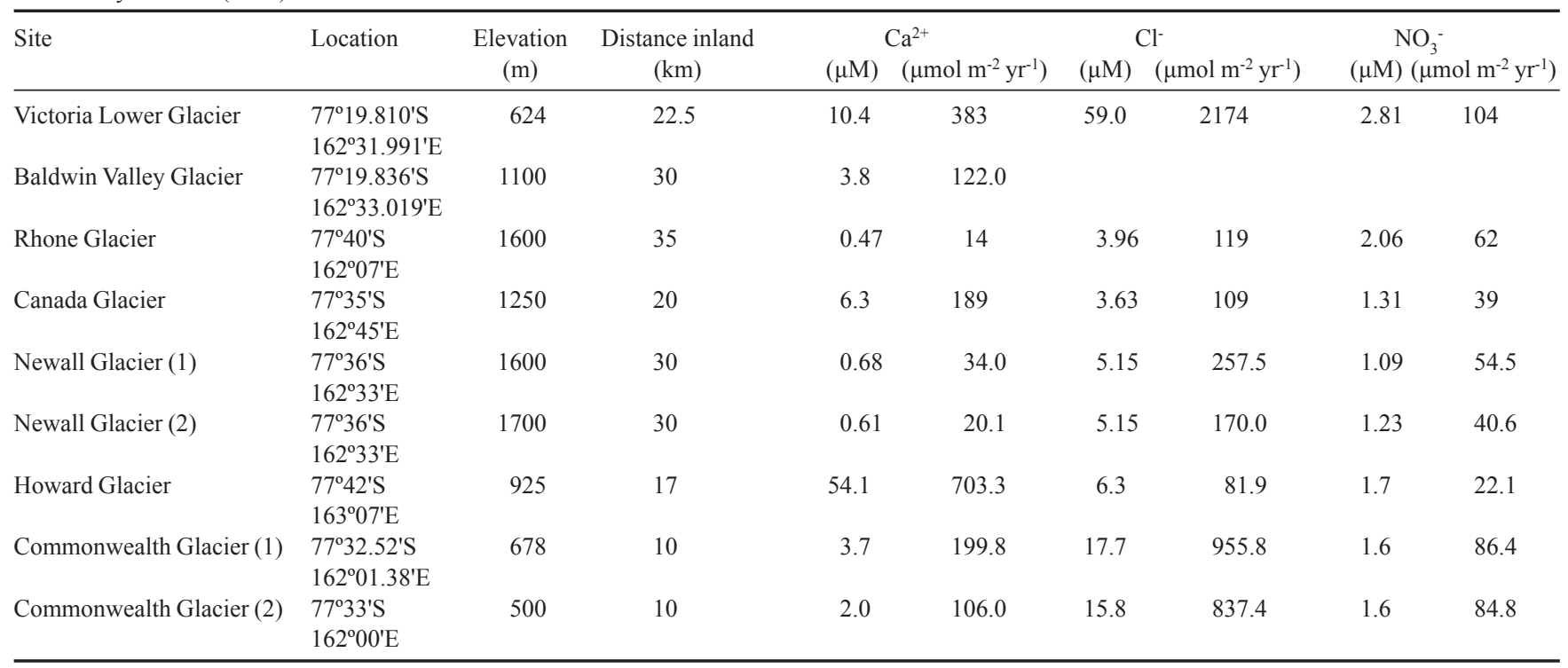


Chloride $(\mathrm{Cl})$

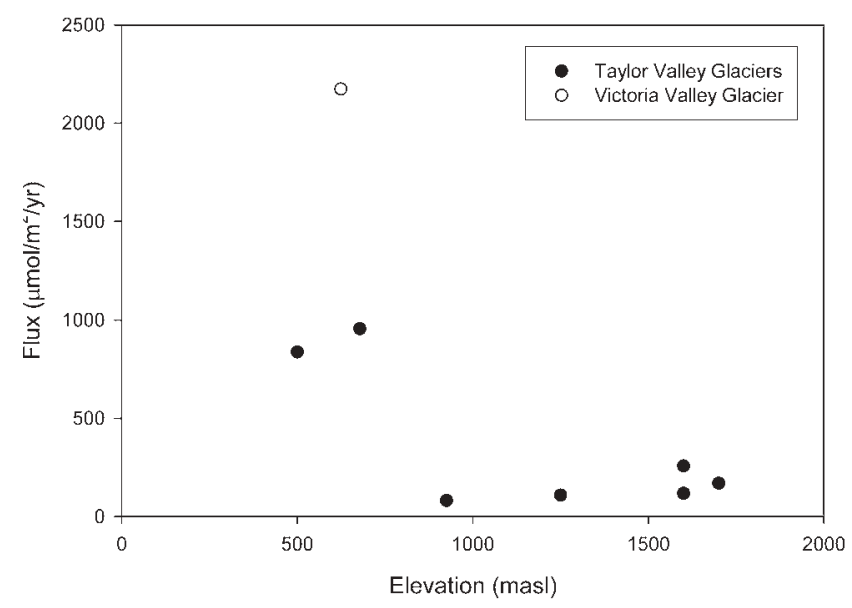

Fig. 3. Snow pit elevation vs $\mathrm{Cl}^{-}$flux for all glacier sites discussed in the text.

$$
f_{a n n}=\left(\sum_{j=1}^{n} f_{j}\right) \cdot n^{-1}
$$

and

$$
f_{j}=C_{j} \cdot b_{j}
$$

where $f_{j}$ is the flux for any given year, $C_{j}$ is the average concentration for a given year, and $b_{j}$ is the accumulation rate for that year. These calculations were within $99 \%$ of the primary determination.

\section{Results}

Fluxes were calculated for all glaciers with known accumulation rates (Table II). The patterns of the geochemical fluxes to these glaciers are spatially complex due to the variety of local sources and proximity to them. The highest fluxes of $\mathrm{NO}_{3}{ }^{-}$and $\mathrm{Cl}^{-}$occur on the Victoria Lower Glacier and the lowest are on the Howard Glacier. The Howard Glacier has by far the highest flux of $\mathrm{Ca}^{2+}$ and the Rhone Glacier has the lowest. The Victoria Lower Glacier is separated from the Ross Sea by a $22.5 \mathrm{~km}$ expanse of Wilson Piedmont Glacier. The Howard Glacier is centrally located in Taylor Valley and is adjacent to the Nussbaum Riegel and surrounded by exposed soil, the likely source of calcium dust (Fig. 1).

The glaciers examined in this study can be grouped by their relative geochemical abundances and locations. The Victoria Lower and Commonwealth Glaciers are at the lowest elevation, closest to the sea, and are characterized by fluxes where $\mathrm{Cl}^{-}>\mathrm{Ca}^{2+}>\mathrm{NO}_{3}^{-}$. The Ross Sea is likely to be the dominant contributor of chloride and a relatively large contributor of calcium in the form of marine aerosol. The marine aerosol $\mathrm{Ca}^{2+}$ flux (based on $\mathrm{Cl}^{-}$data and the $\mathrm{Ca}: \mathrm{Cl}$ seawater ratio) is the largest for these two glaciers, but it is
Calcium $\left(\mathrm{Ca}^{2+}\right)$

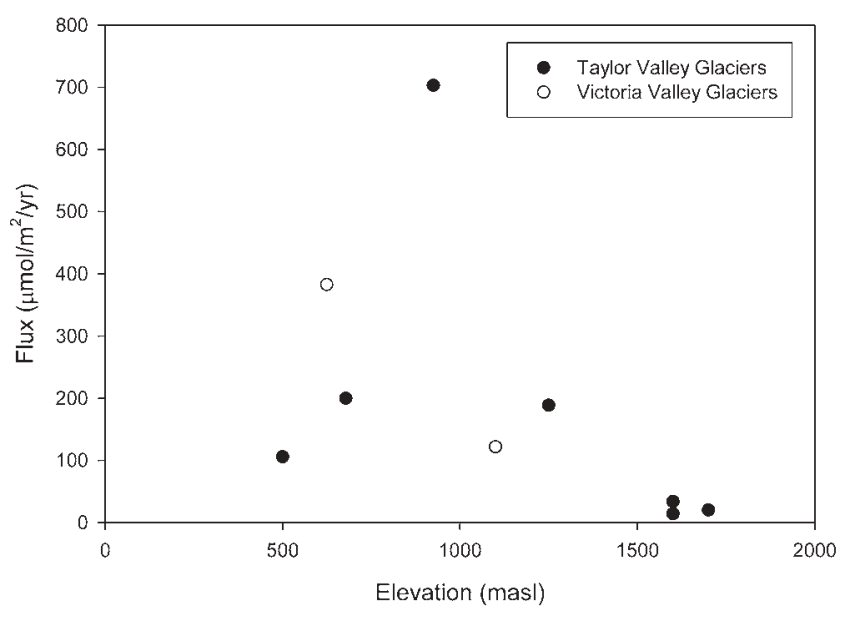

Fig. 4. Elevation vs $\mathrm{Ca}^{2+}$ flux.

only $9-15 \%$ of the total $\mathrm{Ca}^{2+}$ input, suggesting important dust contributions also. The Canada and Howard glaciers, which are situated mid-valley at moderate elevations, differ in that their fluxes are $\mathrm{Ca}^{2+}>\mathrm{Cl}^{-}>\mathrm{NO}_{3}^{-}$. These glaciers are surrounded by ice-free areas and are dominated by local dust deposition and receive only $1.1 \%$ and $0.2 \%$ of their calcium from marine sources. The glaciers at the highest elevations and farthest inland, the Rhone and Newall glaciers, have geochemical fluxes of $\mathrm{Cl}^{-}>\mathrm{NO}_{3}{ }^{-}>\mathrm{Ca}^{2+}$. These glaciers are likely to be more influenced by long distance chloride and nitrate from the Antarctic plateau and receive relatively little local aeolian input compared to other glaciers in the MCM.

Generally, the chloride flux decreases with increasing elevation (Fig. 3). This suggests that the dominant source of chloride originates from the ocean and/or the valley floor as opposed to stratospheric introduction of $\mathrm{HCl}$. Because ELA

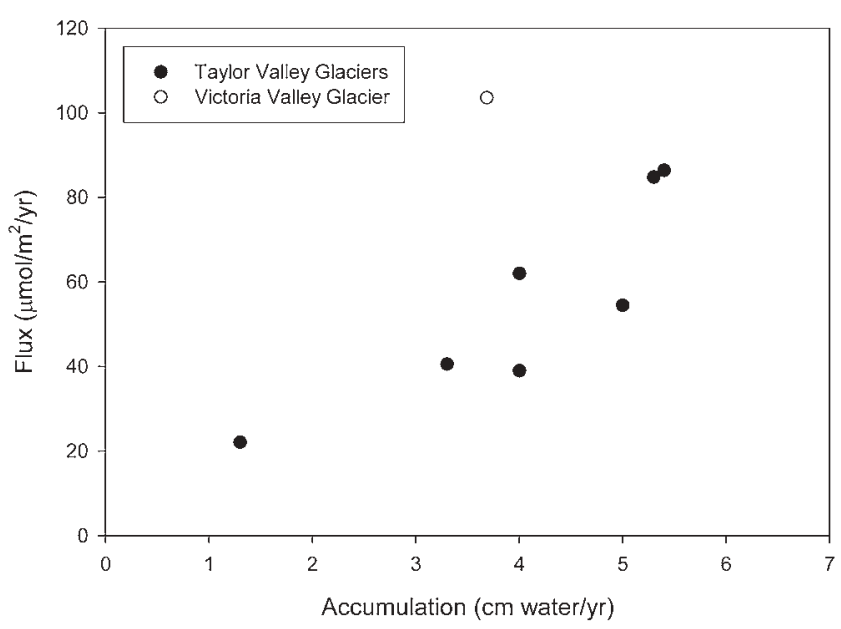

Fig. 5. Accumulation vs $\mathrm{NO}_{3}^{-}$flux. 
in the MCM has a relationship with distance inland (Fountain et al. 1999b), it is difficult to distinguish which variable, either distance inland or elevation, dominates. This is demonstrated in a less well-defined relationship between distance inland and chloride flux (not shown). The weak relationship may be a result of variations in local topography, which inhibit the distribution of sea salt. Calcium flux generally displays a similar decreasing pattern with increasing elevation as was observed by Lyons et al. (2003) (Fig. 4). The glaciers at lower elevations receive moderate to high $\mathrm{Ca}^{2+}$ fluxes due to calcium from sea salt aerosols and proximity to a local dust source such as the valley floor. Calcium and chloride show poor correlations with accumulation (not shown). The nitrate flux in the Taylor Valley has a positive relationship with accumulation indicating that wet deposition dominates (Fig. 5).

\section{Discussion}

Although the soils of the MCM are mostly developed from the weathering of glacial tills, salt deposits can account for $>40 \%$ by volume (Claridge \& Campbell 1977). This is due to the great exposure age of many of the soils (Marchant \& Denton 1996), the long-term atmospheric input of salts and their concentration resulting from evaporation/sublimation processes, and lack of substantial leaching. It is clear from our work and from previous research that the geochemistry of both surface snow and cryoconite holes on the glaciers and the soils in Taylor Valley varies with elevation and proximity to the ocean (Keys \& Williams 1981, Lyons et al. 2003, Porazinska et al. 2004). The flux of windblown particulate matter (i.e. dust) also varies geographically in the MCM (Lancaster 2002), and this too is reflected in the surface snow of the glaciers (Lyons et al. 2003).

Claridge \& Campbell (1977) noted a strong relationship between rock type and the composition of salts in TransAntarctic Mountain soils, indicating that mineral weathering contributes to salt accumulation in these soils. However, the variation in distribution of salts such as $\mathrm{NaCl}$ and $\mathrm{NaNO}_{3}$ strongly suggests that atmospheric deposition is an extremely important process in adding salts to the MCM soils (Keys \& Williams 1981, Bockheim 1997). The concentrations of these soluble salts increase linearly with time and are greatest in the xerous soils (i.e. soils with low moisture primarily derived from vapor) of equivalent age compared to the subxerous (moderate moisture) and ultraxerous (ultra-low moisture) soils (Bockheim 1997). $\mathrm{Na}^{+}$is the dominant soluble cation in most soils, while the anion distribution is related to location, with $\mathrm{Cl}^{-}$most abundant in the lower elevation, coastal sites, and $\mathrm{NO}_{3}{ }^{-}$at the higher elevation, more inland sites (Keys \& Williams 1981, Bockheim 1997). Bockheim (1997) estimated the annual accumulation of atmospherically derived salt in MCM to be between 360 and $680 \mu \mathrm{g} \cdot \mathrm{m}^{-2}$, depending on the location, essentially decreasing inland. For the most inland, ultraxerous soils, the atmospheric contribution accounts for $\sim 90 \%$ of the total soluble salt in the soils; only $\sim 15 \%$ of the total input has been retained suggesting that there is a considerable leaching in these soils (Bockheim 1997).

In Taylor Valley, the primary location of the MCM-LTER project, soil conductivity is highest approximately $30 \mathrm{~km}$ inland, in the Lake Bonney basin, where soil invertebrate abundance is typically very low (Barrett et al. 2004). Throughout Taylor Valley there are low C:N ratios of the mineralizable pools in the soils and $\mathrm{N}$ availability exceeds the biotic demand (Barrett et al. 2005). This is thought to be due in large part to the importance of the atmospheric deposition to the overall $\mathrm{N}$ pool in these soils. Nitrate, in combination with other salts, has been shown to inhibit nematode colonization in the MCM (Nkem et al. 2005). Soil salinity also plays an important role in the biodiversity patterns of the MCM and perhaps has a greater impact than soil moisture (Nkem et al. 2005). For example, the two most common nematodes, Scottnema lindsayae and Plectus antarcticus, display remarkably different tolerances to both salt composition and concentration (Nkem et al. 2005). Because the soil communities in the MCM largely consist of these and other single-celled organisms, atmospheric deposition of salts may be critical in dictating the abundance and diversity of Antarctic biota.

Although the measurement of precipitation is one of the most basic parameters needed to describe the climatological conditions of an environment, the direct measurement of precipitation in Antarctica in general, and the MCM in particular, has proven to be extremely difficult (Bull 1971, Keys 1980). The reasons for this are complex - a large contribution to accumulation can be from blowing snow rather than direct input (Keys 1980), the rapid sublimation and evaporation of snow can occurafter deposition (Keys 1980, Fountain et al. 1999a), and there are difficulties in collecting snow fall in windy conditions (P. Doran, personal communication 2005). Bull (1971) estimated the average annual snowfall in the MCM region to be $15 \mathrm{~cm}$ of water. The measured annual precipitation in MCM has ranged from 0 to $50 \mathrm{~cm}$ (Keys 1980, Bromley 1985). There are marked precipitation gradients in the MCM with more snow in the eastern and far western regions with snowlines lowest in the east (Keys 1980, Fountain et al. 1999b). The limited amount of actual precipitation measurements has led investigators to report the recent annual precipitation in water equivalent to be $<10 \mathrm{~cm}$ (Keys 1980, Doran et al. 2002). This value compares well to a recent assessment of snow accumulation on the East Antarctic Ice Sheet since the 1950s (Monaghan et al. 2006). To date, snow accumulation in the upper region accumulation zones of the glaciers in the MCM have been utilized as the most direct measurement of net accumulation of snow (Anderton \& Fenwick 1976, Fountain et al. 1999b).

Little detailed information exists regarding precipitation rates in the MCM except for that determined by us and 
others on the glaciers themselves. The consensus is that the precipitation rate is $<10 \mathrm{~cm} \cdot \mathrm{yr}^{-1}$ water-equivalent throughout the valleys (Fountain et al. 1999a) but is highly variable. At Lake Vanda over a three year period, snowfall water-equivalent varied between 10 and $0.6 \mathrm{~cm}$ (Bromley 1985). The relative humidity on the valley floors is low with the annual mean ranging from $74 \%$ at Explorer's Cove at the coastline to $62 \%$ at Lake Bonney and $55 \%$ at Lake Vanda (Doran et al. 2002). Any snow can be rapidly sublimed and the ions within the snow left behind in the soils. This is especially the case at higher elevations where little to no liquid water is observed (Marchant \& Denton 1996).

Alley et al. (1995) presented a model relating elemental fluxes to atmospheric concentration and ice (snow) accumulation where:

$$
f_{i}=K_{1} C_{i}+K_{2} C_{i} b
$$

where $K_{1}$ is the dry deposition velocity, $K_{2}$ is the scavenging ratio for precipitation and $C_{i}$ is the concentration of the analyte in the ice (snow). If $K_{1}$ and $K_{2}$ are constants, a plot of flux versus ice (snow) accumulation should yield a straight line with $K_{2} C_{i}$ as the slope and $K_{1} C_{i}$ as the intercept. The intercept can be taken as an approximation of the dry deposition rate (Alley et al. 1995). Only $\mathrm{NO}_{3}{ }^{-}$flux vs snow accumulation produced a relatively straight line $\left(r^{2}\right.$ $=0.8$ ), firstly suggesting that $K_{1}$ and $K_{2}$ are relatively constant for nitrate. The low y-intercept $\left(4.4 \mu \mathrm{mol} \cdot \mathrm{m}^{-2} \cdot \mathrm{yr}^{-1}\right)$ suggests that dry deposition of nitrate in Taylor Valley is extremely low.

The Howard Glacier has the highest non-sea salt $\mathrm{Ca}^{2+}$ concentrations in its accumulation zone of any glacier investigated in Taylor Valley (Lyons et al. 2003). Similarly high particulate matter concentrations observed on Taylor Valley glaciers are also found in the Howard Glacier surface snows (Lyons et al. 2003). These two observations suggest that local dust, enriched in $\mathrm{Ca}^{2+}$, is the source. This $\mathrm{Ca}^{2+}$ rich dust originates from higher elevations above the lower reaches of the Taylor Glacier (Fig. 1) and is transported into Taylor Valley during strong wind events from the polar plateau (Foley 2005). This dust can be differentially distributed onto the glacier surfaces (Lancaster 2002), causing variations in the local glacier surface geochemistry (Lyons et al. 2003). The valley soils must be affected in the same manner as the glaciers. The dust flux probably contributes to heterogeneity in the soluble geochemistry of the soils. Although the total $\mathrm{Ca}^{2+}$ concentration in the soils is clearly dominated by the bedrock composition of the tills, a more labile source of $\mathrm{Ca}^{2+}$ comes from the dust (Foley 2005). This dust derived $\mathrm{Ca}^{2+}$ can be converted to $\mathrm{CaCO}_{3}$ and possibly other $\mathrm{Ca}^{2+}$ rich materials in the soils.

The relationship between $\mathrm{NO}_{3}^{-}$flux and snow accumulation may be a result of volatilization from the glacier surface. Previous work in both Antarctica and
Greenland has demonstrated that in regions with low snow accumulation rates, $\mathrm{NO}_{3}{ }^{-}$is lost from the snowpack (Jones et al. 2001, Röthlisberger et al. 2002). This postdepositional loss of $\mathrm{NO}_{3}{ }^{-}$is caused by release of $\mathrm{HNO}_{3}{ }^{-}$ and/or photolysis with the latter being more important at the lowest snow accumulation sites (Röthlisberger et al. 2002).

Our results provide a comprehensive look at salt deposition in the intermediate elevations of the MCM region. Marine aerosol dominates the input of $\mathrm{Cl}^{-}$with higher fluxes relative to snow accumulation only very close to the coast and at low elevations. $\mathrm{Ca}^{2+}$ input can be modified extensively by aeolian inputs. The $\mathrm{NO}_{3}^{-}$flux is highest where snow accumulation rates can limit postdepositional loss. Based on the data in Fig. 5, the amount of snow accumulation should be the primary driver for $\mathrm{NO}_{3}{ }^{-}$ input into the soils.

The higher elevations of these valleys have very old surfaces that have not been affected by either marine incursion or lake level fluctuation for millions of years (Marchant \& Denton 1996). In these cases, the soils have been accumulating ions via precipitation and subsequent sublimation over very long periods of time resulting in salt accumulation (Bao et al. 2000, Bockheim 2002). Superimposed on this process is the redistribution of salts and aluminosilicates from the bedrock and the soils via aeolian transport (Lancaster 2002). This dust can be transported to the highest elevations of the valleys, as evidenced by ice core investigations in the Asgard Range (Mayewski et al. 1995), even though the rates of aeolian redistributions are among the lowest for desert environments globally (Lancaster 2002).

On some valley floors, like that of the Taylor Valley, as lake levels rise, the previously deposited salt is solubilized and incorporated into the lake water. Over time as the climate cools and lake levels drop, salts are concentrated into the more saline, hypolimnia (Lyons et al. 1998, 2005). This exposes the valley floor as soil again (as opposed to lacustrine benthos) and the accumulation in soils via precipitation begins another cycle. The resultant elemental distributions by these processes have been termed "legacy" (Moorhead et al. 1999, Burkins et al. 2000). Therefore the concentration of salts and the nature of the salt in soils in the MCM region represents a combination of geographic location and elevation that, in part, reflects variations in snow accumulation, the age of the surface and how it relates to its last aquatic submergence and the input and output of dust (especially for $\mathrm{CaCO}_{3}$ ).

\section{Conclusions}

We have determined the fluxes of $\mathrm{Ca}^{2+}, \mathrm{Cl}^{-}$and $\mathrm{NO}_{3}{ }^{-}$to nine glaciers in the McMurdo Dry Valleys. These data provide important new information about the unusual atmospheric input of salts into this polar desert landscape. The data suggest that variation in snowfall is a major influence on 
$\mathrm{NO}_{3}^{-}$input, and other geographic parameters such as proximity to the ocean, elevation, and variation in dust deposition influence elemental fluxes to the landscape. These results indicate that snow pit data can serve as an important source of spatial geochemical information in this environment. Clearly data from other glaciers in the region would add greatly to our overall understanding of the spatial variability in atmospheric deposition to the MCM. However, direct measurements of atmospheric input are needed on the valley floors themselves in order to truly quantify the fluxes at the lowest elevations in these valleys. It is hoped that information such as that presented here, coupled with data on past lake level fluctuations will greatly aid in understanding salt accumulation processes in the MCM soils.

\section{Acknowledgements}

The OSU/PSU portion of this work was supported by NSF grants OPP-0096250 and ANT-0423595. We would like to thank Dr M. Tranter and Dr R. Virginia for their helpful comments on the original manuscript. We are deeply appreciative of the editorial comments and patience of $\mathrm{Dr}$ Jenny Webster-Brown.

\section{References}

Alley, R.B., Finkel, R.C., Nishiizumi, K., Anandakrishnan, S., Shuman, C.A., Mershon, G., Zielinksi, G.A. \& MaYewski, P.A. 1995. Changes in continental and sea-salt atmospheric loadings in central Greenland during the most recent deglaciation: model-based estimates. Journal of Glaciology, 41, 503-514.

Anderton, P.W. \& Fenwick, J.K. 1976. Dry Valleys Antarctica, 1973-1974. New Zealand Hydrological Research, Annual Report, No. 37, $42 \mathrm{pp}$.

BaO, H., Campbell, D.A., Bockheim, J.G. \& Thelmens, M.H. 2000. Origins of sulphate in Antarctic Dry Valley soils as deduced from anomalous ${ }^{17} \mathrm{O}$. Nature, 407, 499-502.

Barrett, J.E., Virginia, R.A., Parsons, A.N. \& Wall, D.H. 2005. Potential soil organic matter turnover in Taylor Valley, Antarctica. Arctic, Antarctic, and Alpine Research, 37, 108-117.

Barrett, J.E., Virginia, R.A., Wall, D.H., Parsons, A.N., Powers, L.E. \& BURKINS, M.B. 2004. Variation in biogeochemistry and soils biodiversity across spatial scales in a polar desert ecosystem. Ecology, 85, 3105-3118.

Bertler, N.A.N., Barrett, P.J., Mayewski, P.A., Fogt R.L., Kreutz, K.J. \& Shulmeister, J. 2004a. El Niño suppresses Antarctic warming. Geophysical Research Letters, 31, doi:10.1029/2004GL020749.

Bertler, N.A.N., Mayewski, P.A., Barrett, P.J., Sneed, S.B., Handley, M.J. \& KreutZ, K.J. 2004b. Monsoonal circulation of the McMurdo Dry Valleys - signal from the snow chemistry. Annals of Glaciology, 39, 139-145.

Bertler, N.A.N., Oerter, H., Kipfstuhl S., Barrett, P.J., Naish, T.R. \& MAYEWSKI, P.A. 2006. The effects of joint ENSO-Antarctic Oscillation forcing on the McMurdo Dry Valleys, Antarctica. Antarctic Science, 18, 507-514.

BockHeim, J.G. 1997. Properties and classification of cold desert soils from Antarctica. Soil Science Society of America, 61, 224-234.

BockHeim, J.G. 2002. Landform and soil development in the McMurdo Dry Valleys, Antarctica: A regional synthesis. Arctic, Antarctic, and Alpine Research, 34, 308-317.
Bowser, C.J., Black, R.F. \& RAFter, T.A. 1970. Geochemical evidence for the origin of mirabilite deposits near Hobbs Glacier, Victoria Land, Antarctica. Special Paper-Fiftieth Anniversary Symposia, Mineralogy and Geochemistry of Non-Marine Evaporites. Mineralogical Society of America, 3, 261-272.

Bromley, A.M. 1985. Weather observations: Wright Valley, Antarctica. Wellington New Zealand: New Zealand Meteorological Service. Information Publication II, 37 pp.

Bull, C. 1971. Snow accumulation in Antarctica. In Quam, C.O. \& PORTER, H.D. eds. Research in the Antarctic. American Association for the Advancement of Science, 367-421.

Burkins, M.B., Virginia, R.A., Chamberlain, C.P. \& Wall, D.H. 2000. Origin and distribution of soil organic matter in Taylor Valley, Antarctica. Ecology, 81, 2377-2391.

Claridge, G.G.C. \& CAmpBell, I.B. 1977. The salts in Antarctic soils, their distribution and relationship to soil processes. Soil Science, 123, 377-384.

Doran, P.T., McKay, C.P., Clow, G.D., Dana, G.L., Fountain, A.G., NYLEN, T. \& LyONS, W.B. 2002. Valley floor climate observations from the McMurdo Dry Valleys, Antarctica, 1986-2000. Journal of Geophysical Research, 107, doi:10.1029/2001JD002045.

FoLey, K.K. 2005. Pedogenic Carbonate Distribution within Glacial Till in Taylor Valley, Southern Victoria Land, Antarctica. MS thesis, The Ohio State University, 105 pp. [Unpublished.]

Fortner, S.K., Tranter, M., Fountain, A., Lyons, W.B. \& Welch, K.A. 2005. The geochemistry of supraglacial streams of Canada Glacier, Taylor Valley (Antarctica), and their evolution into proglacial waters. Aquatic Geochemistry, 11, 391-412.

FountAIN, A.G. 2005. Glacier mass balance summaries. http://metacat.lternet.edu/knb/metacat?action=read\&qformat=lter\&doci $\mathrm{d}=$ knb-lter-mcm. McMurdo Dry Valleys LTER, Columbus, $\mathrm{OH}$.

Fountain, A.G., Lyons, W.B., Burkins, M.B., Dana, G.L., Doran, P.T., Lewis, K.J., McKnight, D.M., Moorhead, D.L., Parsons, A.N., Priscu, J.C., Wall, D.H., Wharton JR, R.A. \& Virginia, R.A. 1999a. Physical controls on the Taylor Valley Ecosystem, Antarctica. Bioscience, 49, 961-971.

Fountain, A.G., Lewis, K.J. \& Doran, P.T. 1999b. Spatial climate variation and its control on glacier equilibrium line altitude in Taylor Valley, Antarctica. Global Planetary Change, 22, 1-10.

GiBson, G.W. 1962. Geological investigations in southern Victoria Land, Antarctica; part 8, Evaporite salts in the Victoria valley region. New Zealand Journal of Geology and Geophysics, 5, 361-374.

Graham, I.J., Ditchburn, R.G., Claridge, G.G.C., Whitehead, N.E., Zondervan, A. \& Sheppare, D.S. 2002. Dating Antarctic soils using atmosphere-derived ${ }^{10} \mathrm{Be}$ and nitrate. Royal Society of New Zealand Bulletin, No. 35, 429-436.

Green, W.J., Newell, S., Preston, A., Shacat, J., Stage, B.R. \& Wagers, S. 2005. Geochemical processes in the Onyx River, Wright Valley, Antarctica; major ions, nutrients, trace metals. Geochimica et Cosmochimica Acta, 69, 839-850.

Gooseff, M.N., Blum, A.E., Lyons, W.B. \& McKnight, D.M. 2002. Weathering reactions and hyporheic exchange controls on stream water chemistry in a glacial meltwater stream in the McMurdo dry valleys. Water Resources Research, 38, doi:10.1029/2001WR000834.

Howard-Williams, C., Peterson, D., Lyons, W.B., Cattaneo-Vietti, R. \& GoRDON, S. 2006. Measuring ecosystem response in a rapidly changing environment: the Latitudinal Gradient Project. Antarctic Science, 18, 465-471.

Jones, A.E., Weller, R., Anderson, P.S., Jacobi, H.-W., Wolff, E.W., Schrems, O. \& Miller, H. 2001. Measurements of $\mathrm{NO}_{\mathrm{x}}$ emission from the Antarctic snowpack. Geophysical Research Letters, 28, 1499-1502.

KeYs, J.R. 1980. Air temperature, wind, precipitation, and atmospheric humidity in the McMurdo region. Victoria University of Wellington Antarctic Data Series, No. 9, 57 pp. 
Keys, J.R. \& Williams, K. 1981. Origin of crystalline, cold desert salts in the McMurdo region, Antarctica. Geochimica et Cosmochimica Acta, 45, 2299-2309.

LANCASTER, N. 2002. Flux of eolian sediment in the McMurdo Dry Valleys, Antarctica: a preliminary assessment. Arctic and Antarctic Alpine Research, 34, 318-323.

LEGRAND, M. \& MAYEWSKI, P.A. 1997. Glaciochemistry of polar ice cores: a review. Reviews of Geophysics, 35, 219-243.

Lyons, W.B., Tyler, S.W., Wharton, R.A., McKnight, D.M. \& Vaughn, B. 1998. A late Holocene desiccation of Lake Hoare and Lake Fryxell, McMurdo Dry Valleys, Antarctica. Antarctic Science, 10, 245-254.

Lyons, W.B., Gooseff, M.N., Maurice, P., McKnight, D.M., Nezat, C.A. \& WeLCH, K.A. 2002. Chemical vs. physical weathering in streams of a polar desert, Antarctica. Abstracts with Programs, Geological Society of America, 34, 450.

Lyons, W.B., Welch, K.A., Fountain, A.G., Dana, G.L., Vaughn, B.H. \& MCKNight, D.M. 2003. Surface glaciochemistry of Taylor Valley, southern Victoria Land, Antarctica and its relationship to stream chemistry. Hydrological Processes, 17, 115-130.

Lyons, W.B., Welch, K.A., Snyder, G., Olesik, J., Graham, E.Y., Marion, G.M. \& PoredA, R.J. 2005. Halogen geochemistry of the McMurdo Dry Valleys Lakes, Antarctica: clues to the origin of solutes and lake evolution. Geochimica et Cosmochimica Acta, 69, 305-323.

Marchant, D.R. \& Denton, G.H. 1996. Miocene and Pliocene paleoclimate of the Dry Valleys region, Southern Victoria Land: a geomorphological approach. Marine Micropaleontology, 27, 253-271.

Mayewski, P.A. \& LyOns, W.B. 1982. Source and climatic implication of the reactive iron and reactive silicate concentration found in a core from Meserve Glacier, Antarctica. Geophysical Research Letters, 9, 190-192.

Mayewski, P.A., Lyons, W.B., Zielinski, G., Twickler, M., Whitlow, S., Dibb, J., Grootes, P., Fosberry, L., Wake, C. \& Welch, K. 1995. An ice core based late Holocene history for the Transantarctic Mountains, Antarctica. Antarctic Research Series, 67, 33-45.

Michalski, G., Bockheim, L.G., Kendall, C. \& Thiemens, M. 2005. Isotopic composition of Antarctic Dry Valley nitrate: implications for $\mathrm{NO}_{\mathrm{y}}$ sources and cycling in Antarctica. Geophysical Research Letters, 32, doi: 10.1029/2004GL022121.

Monaghan, A.J., Bromwich, D.H., Fogt, R.L., Wang, S.H., Mayewski,
P.A., Dixon, D.A., Ekaykin, A., Frezzotti, M., Goodwin, I., Isaksson, E., Kaspari, S.D., Morgan, V.I., Oerter H., Van der Veen, C.J. \& WEN, J. 2006. Insignificant change in Antarctic snowfall since the International Geophysical Year. Science, 313, 827-830.

Moorhead, D.L., Doran, P.T., Fountain, A.G., Lyons, W.B., McKnight, D.M., Priscu, J.C., Virginia, R.A. \& Wall, D.H. 1999. Ecological legacies: impacts on ecosystems of the McMurdo Dry Valleys. Bioscience, 49, 1009-1019.

NezAt, C.A., Lyons, W.B. \& Welch, K.A. 2001. Chemical weathering in streams of a polar desert (Taylor Valley, Antarctica). Geological Society of America Bulletin, 113, 1401-1408.

Nkem, J.N., Virginia, R.A., BARrett, J.E., WALl, D.H. \& Li, G. 2005. Salt tolerance and survival thresholds for two species of Antarctic soil nematodes. Polar Biology, 29, 643-651.

Porazinska, D.L., Fountain, A.G., Nylen, T.H., Tranter, M., Virginia, R.A., WALL, D.H. 2004. The biodiversity and biogeochemistry of cryoconite holes from McMurdo Dry Valley glaciers, Antarctica. Arctic Antarctic and Alpine Research, 36, 84-91.

Powers, L.E., Ho, M., Freckman, D.W. \& Virginia, R.A. 1998 Distribution, community structure, and microhabitats of soil invertebrates along an elevational gradient in Taylor Valley, Antarctica. Arctic and Alpine Research, 30, 133-141.

Röthlisberger, R., Hutterli, M.A., Wolff, E.W., Mulvaney, R., Fischer, H., Bigler, M., Goto-Azuma, K., Hansson, M.E., Ruth, U., Siggard-Andersen, M.-L. \& StefFEnsen, J.P. 2002. Nitrate in Greenland and Antarctic ice cores: a detailed description of postdepositional processes. Annals of Glaciology, 35, 209-216.

Sheppard, D.S., Claridge, G.G.C., Campbell, I.B., Lyon, G.L. \& Rogers, K.M. 2002. The origin of nitrate and sulphate in Antarctic soils. Royal Society of New Zealand Bulletin, 35, 437-411.

Welch, K.A. 1993. Glaciochemical Investigations of the Newall Glacier, Southern Victoria Land, Antarctica. MS thesis, University of New Hampshire, 92 pp. [Unpublished.]

Welch, K.A., Lyons, W.B., Graham, E., Neumann, K., Thomas, J.M. \& MikeselL, D. 1996. Determination of major element chemistry in terrestrial waters from Antarctica by ion chromatography. Journal of Ion Chromatography, A739, 257-263.

Williamson, B.R. 2006 Sources and deposition processes linking atmospheric chemistry and firn records from four glacier accumulation zones in the McMurdo Dry Valleys, Antarctica. MS thesis, University of Maine, [Unpublished]. 
